\title{
Yin-Yang-1 decreases Fas-induced apoptosis in acute lymphoblastic leukemia under hypoxic conditions: its implications in immune evasion
}

\author{
Estefany Martínez-Torres ${ }^{1}$, Tania V. López-Pérez ${ }^{1,2}$, Mario Morales-Martínez ${ }^{3}$, and Sara Huerta-Yepez ${ }^{1 *}$ \\ ${ }^{1}$ Unidad de Investigación en Enfermedades Oncológicas, Hospital Infantil de México Federico Gómez, Mexico City, Mexico; ${ }^{2}$ Consejo Nacional de \\ Ciencia y Tecnología (CONACYT), Unidad de Investigación en Enfermedades Oncológicas, Hospital Infantil de México Federico Gómez, Mexico \\ City, Mexico; ' ${ }^{2}$ Laboratorio de Señalización Molecular en Cáncer Molecular, Hospital de Oncología, Centro Médico Nacional de México Siglo XXI, \\ Instituto Mexicano del Seguro Social (IMSS), Mexico City, Mexico
}

\begin{abstract}
Background: Acute lymphoblastic leukemia (ALL) is an aggressive malignant disease with high prevalence in pediatric patients. It has been shown that the downregulation of Fas expression is correlated with an inadequate response in ALL, although these mechanisms are still not well understood. Several reports demonstrated that hypoxia is involved in dysfunctional apoptosis. Yin-Yang-1 (YY1) transcription factor is involved in resistance to apoptosis, tumor progression, and it is increased in different types of cancer, including leukemia. The regulatory mechanism underlying YY1 expression in leukemia is still not understood, but it is known that YY1 negatively regulates Fas expression. The study aimed to evaluate the effect of YY1 on Fas expression under hypoxic conditions in ALL. Methods: Leukemia cell line RS4; 11 was cultured under normoxic and hypoxic conditions. YY1, Fas receptor, and hypoxia-inducible factor (HIF-1 $\alpha$ ) expression were analyzed. After treatment with a Fas agonist (DX2), apoptosis was analyzed through the detection of active caspase 3. Data were analyzed using Pearson's correlation. Results: Leukemia cells co-expressed both HIF-1 $\alpha$ and YY1 under hypoxia, which correlated with a downregulation of Fas expression. During hypoxia, the levels of apoptosis diminished after DX2 treatment. The analysis revealed that patients with high levels of HIF-1 $\alpha$ also express high levels of YY1 and low levels of Fas. Conclusions: These results suggest that YY1 negatively regulates the expression of the Fas receptor, which could be involved in the escape of leukemic cells from the immune response contributing to the ALL pathogenesis.
\end{abstract}

Key words: Yin-Yang-1. Fas. Hypoxia-inducible factor-1 $\alpha$. Hypoxia. Acute lymphoblastic leukemia.

\section{YY1 induce la disminución de la apoptosis a través de Fas en la leucemia linfoblástica} aguda en condiciones hipóxicas: implicaciones en la evasión de la respuesta inmunitaria

\section{Resumen}

Introducción: La leucemia linfoblástica aguda (LLA) es una enfermedad con alta prevalencia en la población pediátrica. El mecanismo por el cual el receptor de Fas participa en la regulación inmunitaria en los tumores es desconocido, pero se sabe que está subexpresado en LLA. El factor de transcripción Ying-Yang-1 (YY1) está involucrado en la resistencia a la apoptosis y la progresión tumoral; se encuentra aumentado en diferentes tumores, incluida la LLA. Aunque los mecanismos

Correspondence:

*Sara Huerta-Yepez

E-mail: shuertay@gmail.com

Available online: $17-07-2020$

Date of reception: 14-11-2019

Date of acceptance: 05-05-2020

DOI: 10.24875/BMHIM.20000187
Bol Med Hosp Infant Mex. 2020;77(4):186-194

www.bmhim.com 1665-1146/@ 2020 Hospital Infantil de México Federico Gómez. Published by Permanyer. This is an open access article under the CC BY-NC-ND license (http://creativecommons.org/licenses/by-nc-nd/4.0/). 
que regulan la expresión de YY1 en LLA son desconocidos, se sabe que YY1 regula la expresión del receptor de Fas. El objetivo de este trabajo fue evaluar el efecto de YY1 en la expresión de Fas en condiciones de hipoxia en la LLA. Métodos: Se cultivaron células RS4;11 en condiciones de hipoxia y se analizó la expresión de YY1, receptor de Fas y HIF-1 $\alpha$. La apoptosis fue inducida usando un agonista de Fas (DX2) y se analizó con la detección de caspasa 3 activa. Los datos se analizaron mediante correlación de Pearson. Resultados: Las células RS4;11 coexpresaron HIF-1 $\alpha$ y YY1 en hipoxia, lo cual correlaciona con una baja expresión de Fas. La apoptosis se encontró disminuida durante condiciones de hipoxia, después del tratamiento con DX2. El análisis bioinformático mostró que los pacientes con altos niveles de HIF-1a presentan YY1 elevado y bajos niveles del receptor de Fas. Conclusiones: Estos resultados sugieren que YY1 regula negativamente la expresión del receptor de Fas, lo cual podría estar involucrado en el escape de las células leucémicas a la respuesta inmunitaria, contribuyendo a la patogénesis de la LLA.

Palabras clave: YY1. Fas. HIF-1 $\alpha$. Hipoxia. Leucemia linfoblástica aguda.

\section{Introduction}

The concept of cancer immunosurveillance establishes that the immune system can recognize and eliminate cancer cells $\mathbf{s}^{1,2}$. However, cancer cells can escape from this immunosurveillance through several mechanisms, for example, creating an immunosuppressive environment in the tumor, which increases tumor survival or decreases its recognition by the immune system $^{3-7}$. Defective death signaling has been associated with cancer immune escape through overexpression of antiapoptotic proteins, like Bcl-2 or c-Flip, and downregulation of proapoptotic proteins, like Bax or cell death receptors like Fas ${ }^{8,9}$.

Fas (also called Apo1 or CD95) is a member of the tumor necrosis factor receptor superfamily, and after its binding to Fas ligand (FasL), it triggers apoptosis in the cell $^{10}$. Downregulation of Fas in tumors is associated with immune escape $\mathrm{e}^{11-13}$. Evidence suggests that low levels of Fas are associated with inadequate treatment response in leukemia ${ }^{14}$.

Acute lymphoblastic leukemia (ALL) is a malignancy in the bone marrow characterized by the uncontrolled proliferation of lymphoid precursor cells ${ }^{15}$. Patients with ALL have a survival rate of around $80-90 \%{ }^{16}$. However, patients with relapse have a much lower survival rate ${ }^{17-20}$. Some reports have provided evidence on which factors could be playing a critical role in relapse, including hypoxia and dysfunctional apoptosis ${ }^{21}$. Bone marrow biopsies of pediatric ALL overexpress hypoxia-inducible factor $1 \alpha(H I F 1-\alpha)$ compared with healthy bone marrow $^{22}$. A rat model of leukemia has provided evidence that the progression of this disease is associated with an expansion of hypoxic areas in bone marrow ${ }^{23}$.

Interestingly, hypoxia significantly reduces the effects of vincristine, methotrexate, and etoposide $^{23,24}$. Moreover, another transcription factor increased under hypoxia is the Yin-Yang-1 (YY1) transcription factor, which increases significantly in lung microvascular endothelial cells (LMEC), and this increase is maintained for a long duration ${ }^{25}$. Using western blot analysis, Mojiri et al. ${ }^{25}$ found no differences in the levels of total YY1 protein under normoxic and hypoxic conditions; however, when nuclear fractions were analyzed, they found a significant increase of YY1 protein in hypoxia, which suggests that hypoxia induces nuclear translocation of this protein in LMEC ${ }^{25}$.

YY1 can play a dual role since it can repress or promote transcription depending on the cell circumstances ${ }^{26}$. YY1 is overexpressed in several types of cancer such as breast ${ }^{27}$, pancreatic ${ }^{28,29}$, prostate $^{30}$, ovarian $^{31}$, esophagus ${ }^{32}$, osteosarcoma ${ }^{33}$, brain $^{34}$, melanoma $^{35}$, and leukemia ${ }^{26}$. YY1 in cancer has been associated with cancer growth ${ }^{36}$, progression ${ }^{35,37}$, metastasis $^{35,38}$, and poor prognosis ${ }^{36}$.

Recent studies have shown that $Y Y 1$ is increased in patients with non-Hodgkin's lymphoma and leukemia, and its high expression correlates with poor prognosis ${ }^{39}$. Recently, it was demonstrated that $Y Y 1$ regulates the expression of multidrug resistance-1 (MDR1), and its over-expression is correlated with poor prognosis in ALL pediatric patients ${ }^{40}$. Furthermore, a computational analysis has shown that its expression correlates with poor survival in leukemia patients ${ }^{41}$. Importantly, it has been shown that $Y Y 1$ negatively regulates the transcription of $\mathrm{Fas}^{42}$ in ovarian carcinoma ${ }^{43}$ and colorectal cancer cells ${ }^{44}$. However, the role of these transcription factors in the evasion of the immune system through the Fas/ FasL pathway through the negative regulation of Fas by YY1 in ALL is not studied yet. Our first approach hypothesized that $Y Y 1$ is upregulated under hypoxia, and this induces downregulation of Fas expression. This mechanism results in the evasion of apoptosis through the Fas/FasL pathway in ALL cells. A broader understanding of the regulatory mechanisms underlying YY1 
expression and its implications in leukemia, as well as its relationship with Fas downregulation, is important for diagnostic and prognostic purposes. The study aimed to evaluate the effect of $Y Y 1$ on Fas expression under hypoxic conditions in ALL.

\section{Methods}

\section{Cell culture conditions}

The human ALL cell line RS4; 11 was obtained from American Type Culture Collection (Manassas, VA) and cultured in Advanced RPMI Medium (Gibco) supplemented with $4 \%$ fetal bovine serum and $1 \%$ antibiotics. Cells under normoxic conditions were cultured in an incubator (Binder) with $5 \%$ of $\mathrm{CO}_{2}$. For hypoxic conditions, the cells were cultured in a hypoxia chamber (Bactrox), which created an atmosphere of $1 \% \mathrm{O}_{2}, 5 \%$ $\mathrm{CO}_{2}$, and $94 \% \mathrm{~N}_{2}$.

\section{Immunocytochemical analysis of HIF-1 $\alpha$, YY1, and Fas expression}

After treatment, 20,000 cells were placed on slides by duplicate. When dried, the cells were fixed with $4 \%$ paraformaldehyde for $20 \mathrm{~min}$ at $4^{\circ} \mathrm{C}$. Cells were washed twice with phosphate-buffered saline (PBS), and the immunostaining protocol was performed. Briefly, antigen retrieval was performed using sodium citrate $(0.01$ $\mathrm{M}, \mathrm{pH}$ 6.0). Endogenous peroxidase activity was inhibited with methanol and $3 \%$ hydrogen peroxide. The antibody-tissue non-immune binding was blocked by immersing the samples in a universal blocking solution and $1 \%$ albumin bovine serum for $60 \mathrm{~min}$. The samples were incubated overnight at room temperature with an anti-YY1 antibody (dilution 1:2000, Novus Biologicals NBP2-20932), anti-Fas antibody (dilution 1:500, Novus Biologicals NBP1-41407), and anti-HIF-1 $\alpha$ antibody (dilution 1:2000, Novus Biologicals NB100-479). The slides were washed and incubated with a universal link biotinylated antibody (dilution 1:1000) (Dako K069011, California, USA) and then with streptavidin conjugated to horseradish peroxidase; the signal was generated by the addition of diaminobenzidine (DAB) (Dako K346811, California, USA). When the reaction was stopped, samples were counterstained with hematoxylin. The samples were dehydrated, and the preparations were covered with resin and dried at room temperature.

\section{Reverse transcriptase-polymerase chain reaction (RT-PCR)}

Total RNA was isolated from $2 \times 106$ cells using Trizol (Life Technologies) according to the manufacturer's instructions. CDNA synthesis was performed with $1 \mu \mathrm{g}$ of purified RNA using High-Capacity CDNA Reverse Transcription Kit (Applied Biosystems) according to the manufacturer's instructions. Subsequently, the expression of Fas and YY1 was determined by qRT-PCR amplification in a QuantStudio 3 qPCR System (Applied Biosystems) using the TaqMan probes for Fas (HS00236330), YY1 (HS00998747), and TBP (HS00427620) as an endogenous control. PCR conditions were at $50^{\circ} \mathrm{C}$ for $2 \mathrm{~min}$, $95^{\circ} \mathrm{C}$ for $10 \mathrm{~min}$, and 40 cycles at $95^{\circ} \mathrm{C}$ for $15 \mathrm{~s}$ followed by $60^{\circ} \mathrm{C}$ for $1 \mathrm{~min}$. The relative expression levels were calculated using the $2-\Delta \Delta \mathrm{Ct}$ method.

\section{Apoptosis induction}

An apoptosis test was performed to evaluate the relationship between Fas and YY1, in which 300,000 cells were incubated with $2 \mu \mathrm{g}$ of Fas agonist antibody $\left(\mathrm{D} \times 2\right.$, BioLegend) for $9 \mathrm{~h}$ at $37^{\circ} \mathrm{C}$ under normoxic and hypoxic conditions.

\section{Assessment of Fas and active caspase 3 by flow cytometry}

For the assessment of Fas by flow cytometry, cells were cultured under normoxic or hypoxic conditions for 3,6 , and $9 \mathrm{~h}$. Cells were incubated with anti-Fas antibody $\left(0.5 \mu \mathrm{g} / \mathrm{million}\right.$ cells, BioLegend) for $1 \mathrm{~h}$ at $4^{\circ} \mathrm{C}$ in darkness. After incubation, cells were washed twice and resuspended in Fix/FACS solution. The cell fluorescence was analyzed by flow cytometry on a CytoFlex cytometer (Beckman Coulter). A minimum of 10,000 events was analyzed for the generation of each plot. The experiments were performed in triplicate independently.

After apoptosis induction, the percentage of active caspase 3 in cells under normoxia and hypoxia was quantified by flow cytometry. Briefly, cells were incubated for $1 \mathrm{~h}$ at $4^{\circ} \mathrm{C}$ in Cytofix solution (Cytofix/Cytoperm Kit, Biosciences BD) and washed with Perm/Wash solution (Cytofix/Cytoperm Kit, Biosciences BD). Cells were incubated with anti-caspase 3 antibody (dilution 1:50, Bioscience BD) for $1 \mathrm{~h}$ at $4^{\circ} \mathrm{C}$ in darkness. After incubation, cells were washed twice and resuspended in Fix/FACS solution. Cell fluorescence was quantified by flow cytometry on a CytoFlex cytometer (Beckman Coulter). A minimum of 10,000 events was analyzed for 
the generation of each plot. The experiments were performed 3 times.

\section{Terminal deoxynucleotidyl transferase dUTP nick end labeling (TUNEL) assay}

After treatment, 20,000 cells were placed on slides by duplicate. When dried, cells were fixed with $4 \%$ paraformaldehyde for $20 \mathrm{~min}$ at $4^{\circ} \mathrm{C}$ and washed 2 times with PBS, then proceeded to TUNEL protocol. Briefly, antigen retrieval was performed using sodium citrate (0.01 $\mathrm{M}, \mathrm{pH}$ 6.0). Endogenous peroxidase activity was inhibited with methanol and $3 \%$ hydrogen peroxide. The antibody-tissue non-immune binding was blocked by immersing the samples in a $10 \%$ milk-PBS solution for $60 \mathrm{~min}$. Slides were incubated with enzyme solution dilution 1:400 (In situ cell death kit, ROCHE) for $1 \mathrm{~h}$ at $37^{\circ} \mathrm{C}$ in a wet chamber. After three washes with PBS, slides were incubated with TUNEL reaction mixture (In Situ Cell Death Kit, ROCHE) for $1 \mathrm{~h}$ at $37^{\circ} \mathrm{C}$ in a wet chamber. Slides were washed 3 times, and the signal was generated by the addition of DAB (Dako K346811, California, USA). When the reaction was stopped, samples were counterstained with hematoxylin. The samples were dehydrated, and the preparations were covered with resin and dried at room temperature.

\section{Digital image analysis}

Stained slides were digitized at a $40 \times$ magnification using an Aperio ScanScope CS (Aperio, Vista, CA). The Aperio ScanScope CS obtains $40 \times$ images with a spatial resolution of $0.45 \mu \mathrm{m} /$ pixels. The images were reviewed using an ImageScope (Aperio). Once the areas were annotated, they were sent for automated image analysis using Spectrum Software (Aperio). The output from the algorithm returns a quantitative percentage of positive staining.

\section{Bioinformatic analysis of the correlation between Fas and YY1 gene expression in ALL}

An analysis of Fas and YY1 expression levels in ALL patients was performed using a public data set of microarrays retrieved from the Oncomine database and Gene Expression Omnibus, derived from a published analysis reported by Andersson et al..$^{45}$ and Coustan-Smith et al. ${ }^{46}$ The microarray data of Andersson et al. came from 121 childhood leukemias (87 B-linage ALL, 11 T-cell ALL, and 23 acute myeloid leukemia) ${ }^{45}$. In the Coustan-Smith et al. study, the authors analyzed the genome-wide gene expression of bone marrow samples from 270 patients with newly diagnosed childhood ALL versus normal samples $^{46}$. In both studies, the results of HIF-1 $\alpha$, Fas, and YY1 expression were analyzed.

\section{Data processing}

All analyses were processed using the statistics package GraphPad Prism 6 (San Diego, CA.). Data were presented as the arithmetic mean and standard error of each group. The mean differences were determined by two-tailed t-test or by two-way ANOVA followed by Bonferroni's multiple comparisons test. A two-tailed correlation analysis was performed using Pearson's correlation calculations. A $p \leq 0.05$ value was considered statistically significant.

\section{Results}

Hypoxia reduces Fas expression in RS4; 11 cells and is associated with an increase in the expression of HIF-1 $\alpha$ and YY1

Since both HIF-1 $\alpha$ and $Y Y 1$ are overexpressed in hypoxia, we first analyzed their expression in RS4; 11 cells in both normoxic and hypoxic conditions using immunocytochemistry. As shown in figures $1 \mathrm{~A}$ and $\mathrm{B}$, HIF-1 $\alpha$ is significantly overexpressed in RS4; 11 when the cells are under hypoxic conditions $(p=0.001)$ and reached its highest level after $9 \mathrm{~h}$ of hypoxia. A low basal level of HIF-1 $\alpha$ was detected in normoxic conditions. Even when a high baseline level of $Y Y 1$ was observed in normoxia, its expression increased significantly $(p=0.03$ ) under hypoxic conditions and reached its highest level after $9 \mathrm{~h}$ of hypoxia (Fig. $1 \mathrm{C}$ and $\mathrm{D}$ ). Interestingly, Fas is expressed inversely: in hypoxia, Fas expression decreased significantly compared to normoxia ( $p=0.0003$ ) (Fig. 1E). Since we are interested in Fas membrane expression, we performed a flow cytometry assay (Fig. 1F). The highest decrease of Fas was observed after $9 \mathrm{~h}$ of hypoxia, where we found the lowest number of Fas positive cells compared with normoxia (Fig. 1F). Due to this finding, the responses were evaluated at $9 \mathrm{~h}$ in later experiments.

To corroborate our immunocytochemistry results, we analyzed the expression of Fas and $Y Y 1$ by real-time PCR. Our results show that YY1 doubles its expression in hypoxia compared with normoxia $(p=0.0001)$ (Fig. 2A), while Fas decreases four times in hypoxia compared with normoxia ( $p=0.0361$ ) (Fig. $2 B$ ). Our 


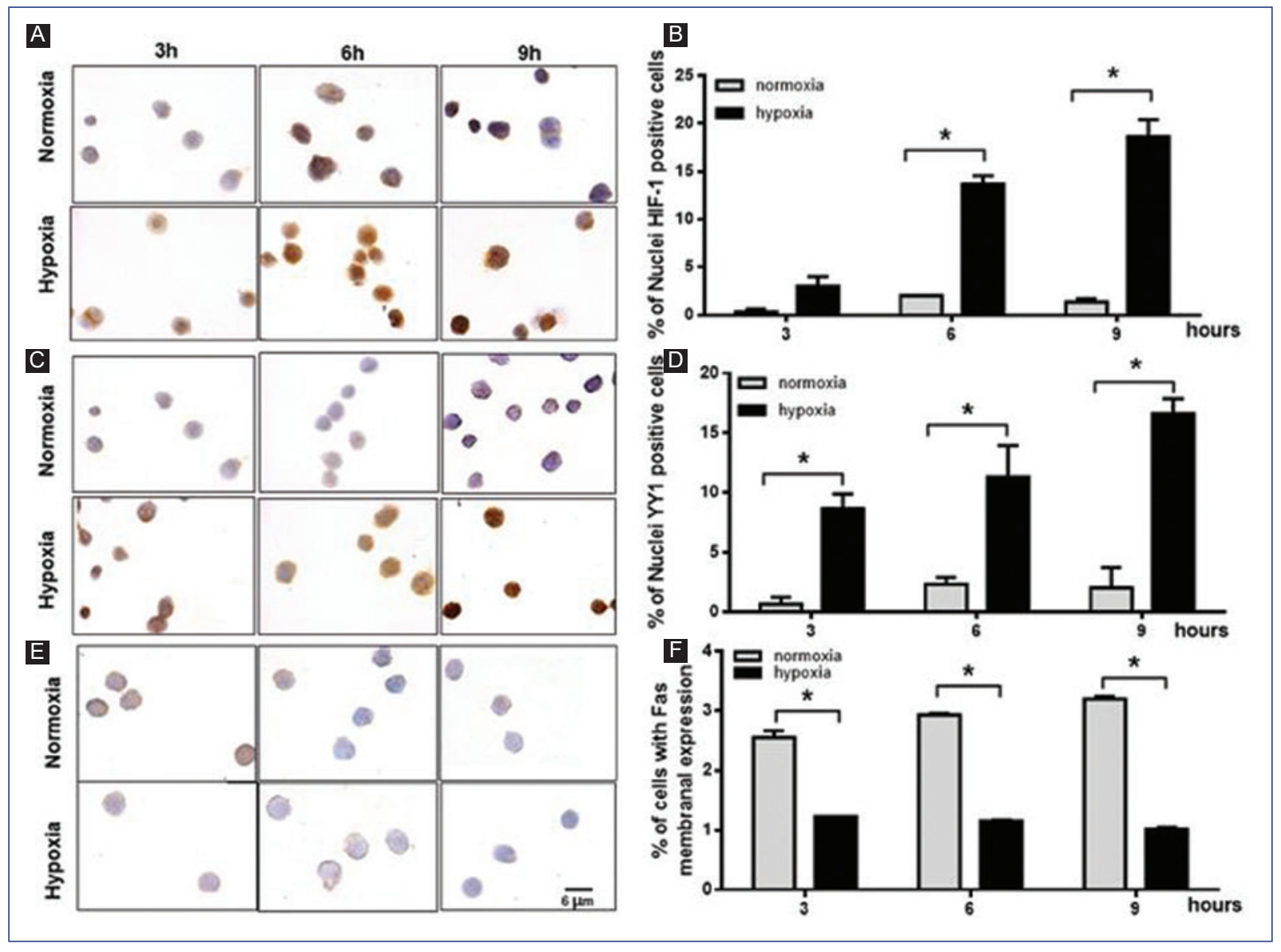

Figure 1. Hypoxia reduces Fas expression in RS4; 11 cells and is associated with an increase in the expression of hypoxia-inducible factor (HIF)-1 $\alpha$ and Yin-Yang-1 (YY1). RS4; 11 cells were incubated under normoxic or hypoxic conditions for 3,6 , and $9 \mathrm{~h}$, and the expression of HIF-1 $\alpha, Y Y 1$, and Fas was analyzed by immunocytochemistry or flow cytometry. Representative microphotographs of HIF1- $\alpha$ A: YY1 C: and Fas E: expression; positive cells are shown in brown. Graphs represent the mean percentage and standard deviation (SE) of nuclei positive cells of HIF1- $\alpha$ B: YY1 D: and Fas membrane expression E: A representative result of three independent experiments is shown. Statistical differences were analyzed by two-way ANOVA followed by Bonferroni's multiple comparisons test. ${ }^{*} p<0.05$.

data suggest that $Y Y 1$ may control Fas expression under hypoxia in the RS4; 11 cell line.

\section{Hypoxia inhibits Fas-related apoptosis}

Due to the decrease of Fas expression under hypoxic conditions, we evaluated cell death by induction of apoptosis with a Fas agonist. First, we treated cells with $2 \mu \mathrm{g} /$ $\mathrm{ml}$ of Fas agonist (DX2) under normoxic and hypoxic conditions and we found that DX2-induced higher apoptosis in normoxia (Fig. 3) compared with hypoxia ( $p=$ 0.0009). To corroborate our results, we analyzed apoptosis by TUNEL in situ and immunocytochemistry of active caspase 3 . We observed a similar effect as mentioned above: cells under normoxia have a higher number of active caspase-3 positive cells as well as TUNEL positive cells when compared with hypoxia ( $p=0.004$ and $p=0.019$, respectively) (Fig. 4). These results show that Fas-related apoptosis is inhibited when cells are under hypoxic conditions, and strongly suggests that hypoxia induces inhibition of Fas/FasL pathway.

\section{Bioinformatics analysis of the correlation between HIF-1 $\alpha$-YY1 and YY1-Fas gene expression in ALL}

The correlation analyses between HIF-1 $\alpha$ versus YY1 and $Y Y 1$ versus Fas in ALL patients were performed using the microarrays data of Andersson et al. ${ }^{45}$ The analysis of Fas and YY1 expression levels in ALL patients was performed using the microarrays data of Coustan-Smith et al. ${ }^{46}$ Our bioinformatics analysis 


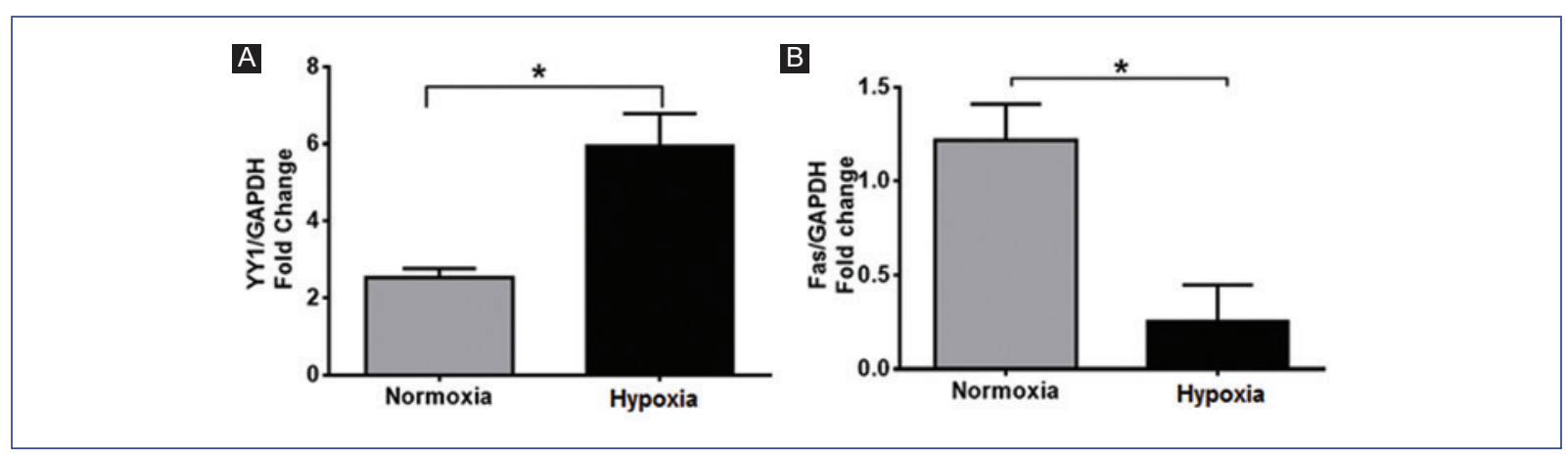

Figure 2. Reverse transcriptase-polymerase chain reaction (RT-PCR) analyses of Yin-Yang-1 (YY1) A: and Fas B: expression. RS4; 11 cells were cultured for $9 \mathrm{~h}$ in normoxia or hypoxia. Graphs represent the mean and standard deviation (SE) of the fold change expression in each condition. A representative result of three independent experiments is shown. Statistical differences were analyzed by Student's t-test. ${ }^{*} p \leq 0.03$.

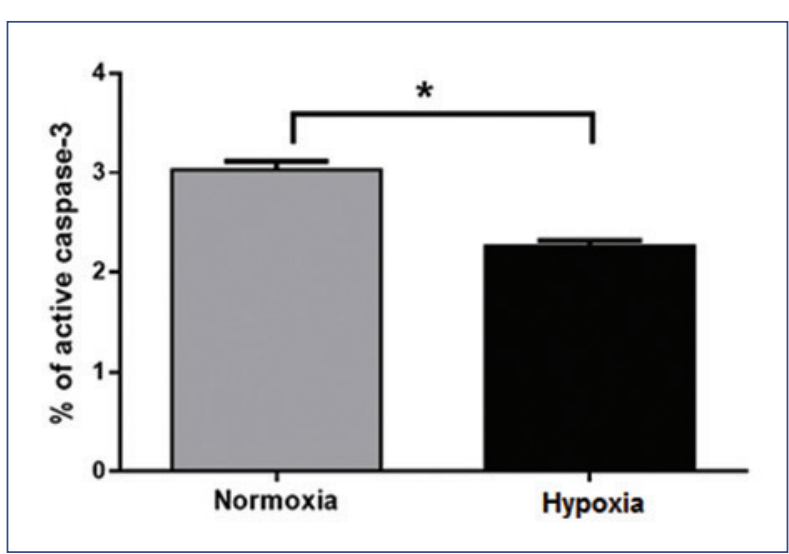

Figure 3. Hypoxia inhibits Fas-related apoptosis. RS4; 11 cells were incubated under normoxia and hypoxia for $9 \mathrm{~h}$ and treated with the Fas agonist, DX2 $(2 \mu \mathrm{g} / \mathrm{ml})$. Analyses of active caspase- 3 were performed by flow cytometry. The graph represents the mean and standard deviation (SE) of the percent of active caspase-3 positive cells in each condition. A representative result of three independent experiments is shown. Statistical differences were analyzed by Student's t-test. ${ }^{*} p=0.0009$.

showed a significant positive correlation for HIF-1 $\alpha$ and YY1 ( $p=0.0005, r=0.3279$ ) (Fig. 5A). No negative correlation between Fas and $Y Y 1$ was found $(p=0.421$, $r=-0.07695)$ (Fig. 5B). We observed that patients with high YY1 expression had low Fas expression; however, the difference in expression between Fas and YY1 was statistically significant ( $p=0.0001)$ (Fig. 6).

\section{Discussion}

The immune system can eliminate damaged cells by the cytotoxic effect of T-cells and natural killer (NK) cells through the interaction of the FasL present in their membrane and Fas present in the target cell. Cancer cells with low Fas expression could evade immune surveillance because they would be insensitive to death signals mediated by NK and T-cells. Perabo et al. showed that bladder cancer cells (BCC) with low Fas expression had higher cell viability and lower apoptotic rate when they were cultured with Fas agonists, as compared with cells with high Fas expression $^{47}$. Furthermore, co-culture experiments of BCC with low Fas expression and Jurkat cells showed that BCC was not killed even by high amounts of Jurkat cells; similar results were obtained in the co-culture of BCC with activated peripheral blood mononuclear cells ${ }^{47}$. In leukemia, low levels of Fas are associated with poor prognosis ${ }^{48}$ and a poor response to the treatment in pediatric $\mathrm{ALL}^{14}$. Our results show that low expression of Fas results in a low rate of apoptosis when cells are treated with a Fas agonist, and interestingly, we show a correlation between low Fas levels and YY1 overexpression under hypoxic conditions in leukemia cells. Similar results were obtained from a computational analysis of public microarrays available in Oncomine and Gene Expression Omnibus of bone marrow samples.

Hypoxia is a state of low oxygen resulting in the stabilization of HIF1- $\alpha$, which triggers the transcription of many downstream hypoxia-inducible gene targets. Pediatric $^{22}$ and adult ${ }^{24}$ patients with ALL, overexpress HIF1- $\alpha$, and the expansion of hypoxic areas in bone marrow is associated with leukemia progression ${ }^{23}$. In this study, we show that overexpression of HIF1- $\alpha$ is correlated with nuclear overexpression of YY1 in ALL cells, suggesting that $Y Y 1$ regulation could be associated with HIF1- $\alpha$ expression. Mojiri et al. ${ }^{25}$ showed that 


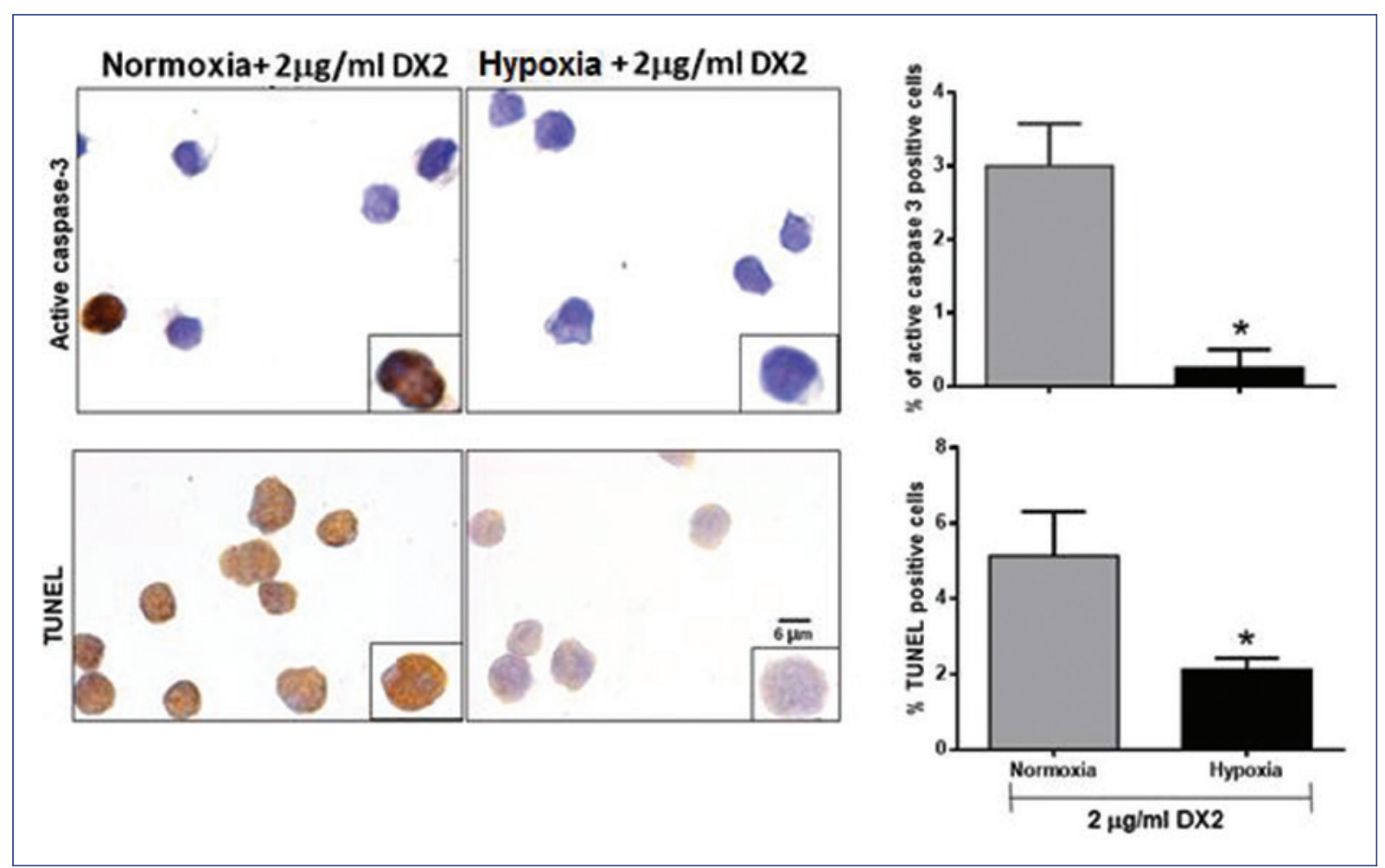

Figure 4. Analysis of apoptosis in RS4; 11 cells. Cells were incubated under normoxia and hypoxia for $9 \mathrm{~h}$ and treated or untreated with the Fas agonist, DX2 $(2 \mu \mathrm{g} / \mathrm{ml})$. Apoptosis was evaluated by terminal deoxynucleotidyl TUNEL in situ and immunocytochemistry of active caspase-3. Representative microphotographs of positive apoptotic cells are shown in brown. Graphs represent the mean and standard deviation (SE) of the percent of positive cells in each condition. A representative result of three independent experiments is shown. Statistical differences were analyzed by Student's t-test. ${ }^{*} p \leq 0.01$.
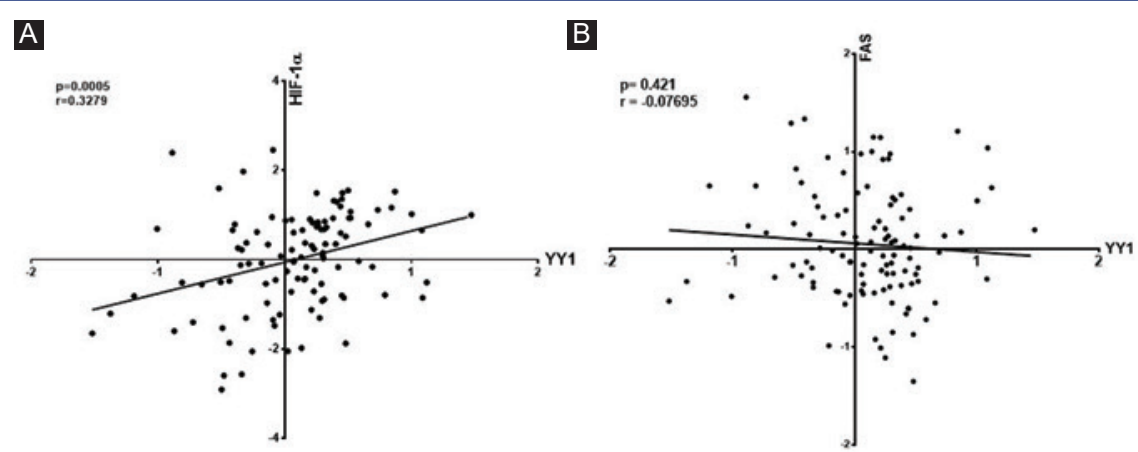

Figure 5. Correlation analyses of hypoxia-inducible factor (HIF-1 $\alpha$ )- Yin-Yang-1 (YY1) and YY1-Fas in leukemia patients. Bioinformatics analysis was done using Oncomine and Gene Expression Omnibus Data Bases. A: Pearson correlation analyses of HIF-1 $\alpha$ and YY1 ( $p=0.0005, r=0.3279)$. B: Pearson correlation analyses of YY1 and Fas $(p=0.421$, $r=-0.07695$ ). Each point represents one leukemia patient.

YY1 mRNA levels increase in response to hypoxia in LMEC. Furthermore, LMEC increased the nuclear translocation of $\mathrm{YY1}$ under hypoxic conditions ${ }^{25}$.
Nuclear expression of YY1 in cancer has been associated with a shorter survival ${ }^{49}$, poor prognosis ${ }^{33,49}$, and metastasis $^{33,38}$. 


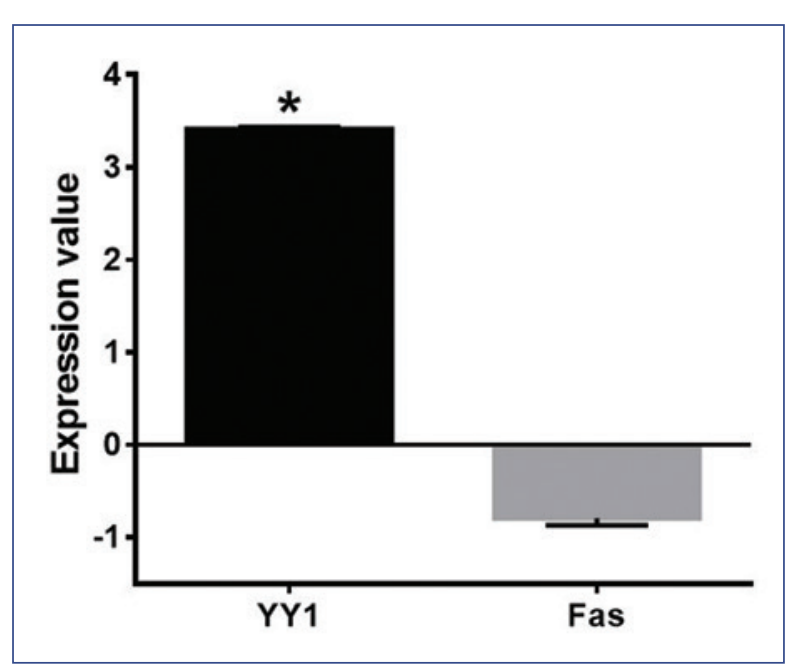

Figure 6. Relation of $Y Y 1$ and Fas expression in samples from ALL patients. Graphs represent the mean and standard deviation (SE) of $Y Y 1$ and Fas expression. A representative result of three independent experiments is shown. Statistical differences were analyzed by Student's t-test. ${ }^{*} p=0.0001$.

Nuclear translocation of $Y Y 1$ is crucial since $Y Y 1$ acts as a transcription factor and can regulate the transcription of $10 \%$ of human genes ${ }^{50}$. In this study, we show a high nuclear expression of $Y Y 1$, which could downregulate Fas expression in leukemia. It has been previously reported that $Y Y 1$ suppresses Fas transcription in ovarian cancer ${ }^{43}$ and colorectal cancer cells ${ }^{44}$. ALL patients with low expression of proapoptotic proteins like caspase 3 , caspase 8 , and Fas have low induction treatment response ${ }^{14}$, and this expression is an independent predictor for poor progno$\mathrm{sis}^{48}$. Interestingly, the downregulation of $Y Y 1$ resensitizes cancer cells to Fas-induced apoptosis ${ }^{44}$. Taking all these observations together, we propose that hypoxia could be a way to evade the immune system, as this condition produces low Fas expression through YY1. This suggestion could partially explain the poor prognosis observed in cancer patients with high YY1 levels.

Patients with high YY1 expression have low Fas levels, as shown by our results and the results of others ${ }^{45,46}$. A possible reason as to why we did not find a negative correlation between $Y Y 1$ and Fas may be due to the low sample size of our study. More studies should be done to establish a possible negative correlation between Fas and $Y Y 1$, in addition to other factors that could affect Fas expression in leukemia.

Our results show that low Fas expression due to hypoxia generates resistance to apoptosis in leukemic cells, which was determined by the lower number of dead cells after treatment with a Fas agonist in comparison with cells under normoxic conditions, which may be a way to evade the immune system.

In conclusion, hypoxia is a critical condition for the immune escape of LLA cells since this condition allows Fas downregulation through YY1 and confers apoptosis resistance.

\section{Ethical disclosures}

Protection of human and animal subjects. The authors declare that no experiments were performed on humans or animals for this study.

Confidentiality of data. The authors declare that they have followed the protocols of their work center on the publication of patient data.

Right to privacy and informed consent. The authors have obtained the written informed consent of the patients or subjects mentioned in the article. The corresponding author has this document.

\section{Conflicts of interest}

The authors declare no conflicts of interest.

\section{Funding}

Federal funds project HIM/2011/009.

\section{Acknowledgments}

The authors would like to thank the Consejo Nacional de Ciencia y Tecnología (CONACYT), the Mexican Federal Funds of the Hospital Infantil de Mexico Federico Gomez, the Mexican Foundation of Health and Merck, and El Patronato del Hospital Infantil de Mexico. The authors also want to thank Shaheen Abkenari for the great support in the preparation of the manuscript.

Estefany Martinez-Torres is a doctoral student from Programa de Doctorado en Ciencias Biomédicas, Universidad Nacional Autónoma de México (UNAM), and received fellowship 509142 from CONACYT.

\section{References}

1. Dunn GP, Bruce AT, Ikeda H, Old LJ, Schreiber RD. Cancer immunoediting: from immunosurveillance to tumor escape. Nat Immunol. 2002;3:991-8.

2. Khong HT, Restifo NP. Natural selection of tumor variants in the generation of "tumor escape" phenotypes. Nat Immunol. 2002;3:999-1005.

3. Bateman AC. Molecules in cancer immunotherapy: benefits and side effects. J Clin Pathol. 2019;72:20-4.

4. Vanichapol T, Chutipongtanate S, Anurathapan U, Hongeng S. Immune escape mechanisms and future prospects for immunotherapy in neuroblastoma. Biomed Res Int. 2018;2018:1812535. 
5. Rabinovich GA, Gabrilovich D, Sotomayor EM. Immunosuppressive strategies that are mediated by tumor cells. Annu Rev Immunol. 2007;25:267-96.

6. Vicari AP, Caux C, Trinchieri G. Tumour escape from immune surveillance through dendritic cell inactivation. Semin Cancer Biol. 2002;12:33-42.

7. Huang B, Zhao J, Li H, He KL, Chen Y, Chen SH, et al. Toll-like receptors on tumor cells facilitate evasion of immune surveillance. Cancer Res. 2005;65:5009-14.

8. French LE, Tschopp J. Defective death receptor signaling as a cause of tumor immune escape. Semin Cancer Biol. 2002;12:51-5.

9. Fulda S, Debatin KM. Death receptor signaling in cancer therapy. Curr Med Chem Anticancer Agents. 2003;3:253-62.

10. Strasser A, Jost PJ, Nagata S. The many roles of FAS receptor signaling in the immune system. Immunity. 2009;30:180-92.

11. Huang R, Zhang D, Li F, Xiao Z, Wu M, Shi D, et al. Loss of Fas expression and high expression of HLA-E promoting the immune escape of early colorectal cancer cells. Oncol Lett. 2017;13:3379-86.

12. Xiao W, Ibrahim ML, Redd PS, Klement JD, Lu C, Yang D, et al. Loss of Fas expression and function is coupled with colon cancer resistance to immune checkpoint inhibitor immunotherapy. Mol Cancer Res. 2019;17:420-30.

13. Paschall AV, Yang D, Lu C, Choi JH, Li X, Liu F, et al. H3K9 trimethylation silences fas expression to confer colon carcinoma immune escape and 5-fluorouracil chemoresistance. J Immunol. 2015;195:1868-82.

14. Mata JF, SilveiraVS, Mateo EC, Cortez MA, Queiroz RG, Yunes JA, et al. Low mRNA expression of the apoptosis-related genes CASP3, CASP8 and FAS is associated with low induction treatment response in childhood acute lymphoblastic leukemia (ALL). Pediatr Blood Cancer. 2010;55:100-7.

15. Purizaca J, Contreras-Quiroz A, Dorantes-Acosta E, Vadillo E, Arriaga-Pizano L, Fuentes-Figueroa S, et al. Lymphoid progenitor cells from childhood acute lymphoblastic leukemia are functionally deficient and express high levels of the transcriptional repressor Gfi-1. Clin Dev Immunol. 2013;2013:349067.

16. St. Jude Children's Research Hospital. Memphis: Acute Lymphoblastic Leukemia (ALL). Available from: https://www.stjude.org/disease/acute-lymphoblastic-leukemia-all.html.

17. Mullighan CG, Phillips LA, Su X, Ma J, Miller CB, Shurtleff SA, et al Genomic analysis of the clonal origins of relapsed acute lymphoblastic leukemia. Science. 2008;322:1377-80.

18. Nguyen K, Devidas M, Cheng SC, La M, Raetz EA, Carroll WL, et al Factors influencing survival after relapse from acute lymphoblastic leukemia: a children's oncology group study. Leukemia. 2008;22:2142-50

19. Chessells JM, Veys P, Kempski H, Henley P, Leiper A, Webb D, et al Long-term follow-up of relapsed childhood acute lymphoblastic leukaemia. Br J Haematol. 2003;123:396-405.

20. Smith L, Glaser AW, Kinsey SE, Greenwood DC, Chilton L, Moorman AV, et al. Long-term survival after childhood acute lymphoblastic leukaemia: population-based trends in cure and relapse by clinical characteristics. Br J Haematol. 2018;182:851-8.

21. Muz B, de la Puente P, Azab F, Azab AK. The role of hypoxia in cancer progression, angiogenesis, metastasis, and resistance to therapy. Hypoxia (Auckl). 2015;3:83-92.

22. Wellman S, Guschmann M, Griethe W, Eckert C, von Stackelberg A, Lottaz C, et al. Activation of the HIF pathway in childhood ALL, prognostic implications of VEGF. Leukemia. 2004;18:926-33.

23. Benito J, Shi Y, Szymanska B, Carol H, Boehm I, Lu H, et al. Pronounced hypoxia in models of murine and human leukemia: high efficacy of hypoxia-activated prodrug PR-104. PLoS One. 2011:6:1-14.

24. Frolova O, Samudio I, Benito J, Jacamo R, Kornblau SM, Markovic A, et al. Regulation of HIF-1 $\alpha$ signaling and chemoresistance in acute lymphocytic leukemia under hypoxic conditions of the bone marrow microenvironment. Cancer Biol Ther. 2012;13:858-70.

25. Mojiri A, Nakhaii-Nejad M, Phan WL, Kulak S, Radziwon-Balicka A, Jurasz $P$, et al. Hypoxia results in upregulation and de novo activation of von Willebrand factor expression in lung endothelial cells. Arterioscler Thromb Vasc Biol. 2013;33:1329-38.

26. Khachigian LM. The yin and yang of YY1 in tumor growth and suppression. Int J Cancer. 2018:143:460-5

27. Allouche A, Nolens G, Tancredi A, Delacroix L, Mardaga J, Fridman V, et al. The combined immunodetection of AP-2alpha and YY1 transcription factors is associated with ERBB2 gene overexpression in primary breast tumors. Breast Cancer Res. 2008:10:1-11.

28. Zhang JJ, Zhu Y, Xie KL, Peng YP, Tao JQ, Tang J, et al. Yin Yang-1 suppresses invasion and metastasis of pancreatic ductal adenocarcinoma by downregulating MMP10 in a MUC4/ErbB2/p38/MEF2C-dependent mechanism. Mol Cancer. 2014;13:1-17.
29. Zhang JJ, Zhu Y, Yang C, Liu X, Peng YP, Jiang KR, et al. Yin Yang-1 increases apoptosis through Bax activation in pancreatic cancer cells. Oncotarget. 2016;7:28498-509.

30. Seligson D, Horvath S, Huerta-Yepez S, Hanna S, Garban H, Roberts A, et al. Expression of transcription factor Yin Yang 1 in prostate cancer. Int J Oncol. 2005;27:131-41

31. Berchuck A, Iversen ES, Lancaster JM, Pittman J, Luo J, Lee P, et al. Patterns of gene expression that characterize long-term survival in advanced-stage serous ovarian cancers. Clin Cancer Res. 2005; 11:3686-96.

32. Luo J, Zhou X, Ge X, Liu P, Cao J, Lu X, et al. Upregulation of Ying Yang 1 (YY1) suppresses esophageal squamous cell carcinoma development through heme oxygenase-1. Cancer Sci. 2013;104:1544-51.

33. de Nigris F, Zanella L, Cacciatore F, De Chiara A, Fazioli F, Chiappetta G, et al. YY1 overexpression is associated with poor prognosis and metastasis-free survival in patients suffering osteosarcoma. BMC Cancer. 2011;11:1-7.

34. Baritaki S, Chatzinikola AM, Vakis AF, Soulitzis N, Karabetsos DA Neonakis I, et al. YY1 over-expression in human brain gliomas and meningiomas correlates with TGF-beta1, IGF-1 and FGF-2 mRNA levels. Cancer Invest. 2009;27:184-92.

35. Zhao G, Li Q, Wang A, Jiao J. YY1 regulates melanoma tumorigenesis through a miR-9 RYBP axis. J Exp Clin Cancer Res. 2015;34:1-11.

36. Zhang N, Li X, Wu CW, Dong Y, Cai M, Mok MT, et al. MicroRNA-7 is a novel inhibitor of $Y Y 1$ contributing to colorectal tumorigenesis. Oncogene. 2013;32:5078-88.

37. Zheng L, Chen Y, Ye L, Jiao W, Song H, Mei H, et al. miRNA-584-3p inhibits gastric cancer progression by repressing Yin Yang 1-facilitated MMP-14 expression. Sci Rep. 2017;7:1-14.

38. Zapata-Tarres M, Juarez-Villegas LE, Maldonado-Valenzuela A, Baay-Guzman GJ, Lopez-Perez TV, Cabrera-Muñoz L, et al. Expression of YY1 in Wilms tumors with favorable histology is a risk factor for adverse outcomes. Future Oncol. 2019;15:1231-41.

39. Moralez-Martinez M, Valencia-Hipolito A, Vega GG, Neri N, Nambo MJ, Alvarado I, et al. Regulation of Krüppel-Like Factor 4 (KLF4) expression through the transcription factor Yin-Yang 1 (YY1) in non-Hodgkin B-cell lymphoma. Oncotarget. 2019;10:2173-88.

40. Antonio-Andrés G, Rangel-Santiago J, Tirado-Rodríguez B, Martinez-Ruiz GU, Klunder-Klunder M, Vega MI, et al. Role of Yin Yang-1 (YY1) in the transcription regulation of the multi-drug resistance (MDR1) gene. Leuk Lymphoma. 2018;59:2628-38.

41. Hafsi S, Candido S, Maestro R, Falzone L, Soua Z, Bonavida B, et al. Correlation between the overexpression of Yin Yang 1 and the expression levels of miRNAs in Burkitt's lymphoma: a computational study. Oncol Lett. 2016;11:1021-5.

42. Motta G, Cea M, Moran E, Carbone F, Augusti V, Patrone F, et al. Monoclonal antibodies for non-Hodgkin's lymphoma: state of the art and perspectives. Clin Dev Immunol. 2010;2010:428253.

43. Garbán HJ, Bonavida B. Nitric oxide inhibits the transcription repressor Yin-Yang 1 binding activity at the silencer region of the Fas promoter: a pivotal role for nitric oxide in the up-regulation of Fas gene expression in human tumor cells. J Immunol. 2001;167:75-81.

44. Pothoulakis C, Torre-Rojas M, Duran-Padilla MA, Gevorkian J, Zoras O Chrysos $E$, et al. CRHR2/Ucn2 signaling is a novel regulator of miR-7/ YY1/Fas circuitry contributing to reversal of colorectal cancer cell resistance to Fas-mediated apoptosis. Int J Cancer. 2018:142:334-46.

45. Andersson A, Ritz C, Lindgren D, Edén P, Lassen C, Heldrup J, et al. Microarray-based classification of a consecutive series of 121 childhood acute leukemias: prediction of leukemic and genetic subtype as well as of minimal residual disease status. Leukemia. 2007;21:1198-203.

46. Coustan-Smith E, Song G, Clark C, Key L, Liu P, Mehrpooya M, et al. New markers for minimal residual disease detection in acute lymphoblastic leukemia. Blood. 2011:117:6267-76.

47. Perabo FG, Kamp S, Schmidt D, Lindner H, Steiner G, Mattes RH, et al. Bladder cancer cells acquire competent mechanisms to escape Fas-mediated apoptosis and immune surveillance in the course of malignant transformation. Br J Cancer. 2001;84:1330-8.

48. Suminoe A, Matsuzaki A, Hattori H, Koga Y, Kinukawa N, Ishii E, et al. mRNA expression of apoptosis-associated genes in infant acute lymphoblastic leukemia: low Fas expression is an independent predictor for poor prognosis. Leukemia. 2004;18:365-8.

49. Kang W, Tong JH, Chan AW, Zhao J, Dong Y, Wang S, et al. Yin Yang 1 contributes to gastric carcinogenesis and its nuclear expression correates with shorter survival in patients with early-stage gastric adenocarcinoma. J Transl Med. 2014;12:1-11.

50. Bonavida B, Kaufhold S. Prognostic significance of $Y Y 1$ protein expression and mRNA levels by bioinformatics analysis in human cancers: a therapeutic target. Pharmacol Ther. 2015;150:149-68. 